\title{
Tumor uptake in glioblastoma multiforme after IV injection of [ $\left.{ }^{177} \mathrm{Lu}\right]$ Lu-PSMA-617
}

\author{
Jolanta Kunikowska ${ }^{1}$ (D) Ingeborga Charzyńska ${ }^{1} \cdot$ Radosław Kuliński $^{1} \cdot$ Dariusz Pawlak $^{2} \cdot$ Michał Maurin $^{2}$. \\ Leszek Królicki ${ }^{1}$
}

Received: 10 January 2020 / Accepted: 3 February 2020 / Published online: 10 February 2020

(C) The Author(s) 2020

Glioblastoma multiforme (GBM) is the most malignant primary brain tumor with limited treatment options in case of recurrence. Prostate-specific membrane antigen (PSMA) expression was demonstrated in microvascular endothelium of $\mathrm{GBM}$ and in vivo confirmed by $\left[{ }^{68} \mathrm{Ga}\right] \mathrm{Ga}$-PSMA-11 PET/CT in primary as well in recurrence tumor [1-4]. This knowledge opens a new way for targeted, PSMA-based treatment. However, it was suggested that uptake not in tumor cells, but in microvascular endothelium, could be characterized by quick washout.

A 54-year-old man 3 years after primary treatment including surgery and chemo-radiotherapy, with a recurrence of GBM revealed in the follow-up MRI, was referred for $\left[{ }^{68} \mathrm{Ga}\right] \mathrm{Ga}$-PSMA-11 PET/CT. The image demonstrated increased, homogenous uptake in the right parietal mass
(SUVmax 10.3) with the tumor-to-liver ratio of 1.8. The patient was disqualified from surgery and radiotherapy and refused chemotherapy. $\left[{ }^{177} \mathrm{Lu}\right] \mathrm{Lu}-\mathrm{PSMA}-617$ treatment was performed $(8.39 \mathrm{GBq})$ with a dosimetry study [5].

The post-therapy images showed increased uptake in tumor mass during the first $24 \mathrm{~h}$, with slow, decreased accumulation up to 14 days. The uptake in normal organs increased up to $3 \mathrm{~h}$ post injection and rapidly decreased in the next days (Figs. 1 and 2). The absorbed dose for the tumor was $14.07 \mathrm{~Gy}$, kidney $0.14 \mathrm{~Gy}$, liver $1.67 \mathrm{~Gy}$, and for whole body 0.49 Gy. To our knowledge, dosimetry study in the treatment of GBM with $\left[{ }^{177} \mathrm{Lu}\right] \mathrm{Lu}-\mathrm{PSMA}-617$ has not been previously reported. The post-therapy images proved the possibility of targeted therapy with $\alpha / \beta$ emitters with no quick as postulated washout in the tumor.

This article is part of the Topical Collection on Image of the month.

Jolanta Kunikowska

jolanta.kunikowska@wum.edu.pl

1 Department of Nuclear Medicine, Medical University of Warsaw, ul. Banacha 1 a, 02-097 Warsaw, Poland

2 Radioisotope Centre POLATOM, National Centre for Nuclear Research, Otwock-Świerk, Poland 

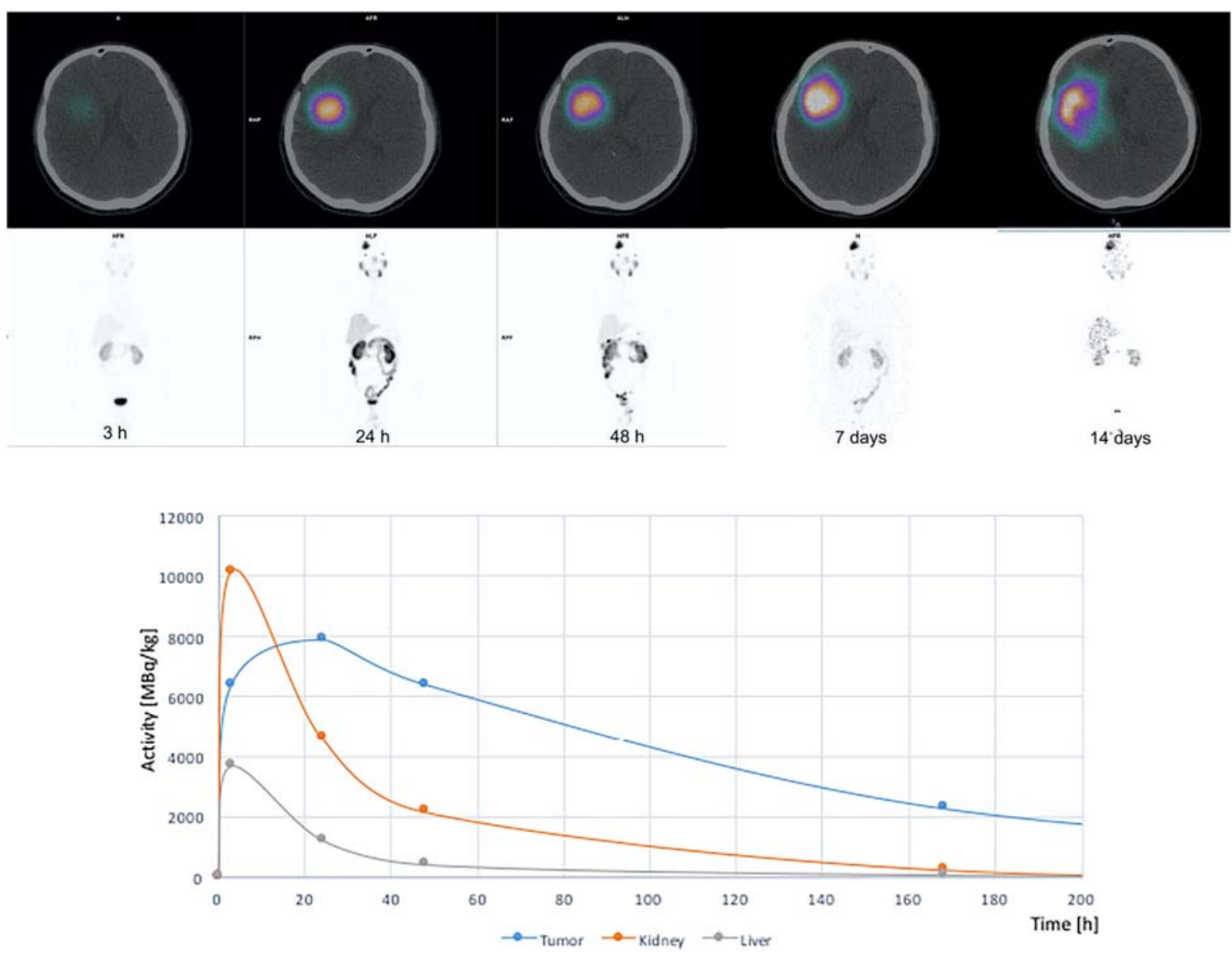

\section{Compliance with ethical standards}

This article does not contain any studies with animals performed by any of the authors. All procedures performed in studies involving human participants were in accordance with the ethical standards of the institutional and/or national research committee and with the 1964 Helsinki declaration and its later amendments or comparable ethical standards. Informed consent was obtained from the individual participant included in the study.

Conflict of interest The authors declare that they have no conflict of interest.

Open Access This article is licensed under a Creative Commons Attribution 4.0 International License, which permits use, sharing, adaptation, distribution and reproduction in any medium or format, as long as you give appropriate credit to the original author(s) and the source, provide a link to the Creative Commons licence, and indicate if changes were made. The images or other third party material in this article are included in the article's Creative Commons licence, unless indicated otherwise in a credit line to the material. If material is not included in the article's Creative Commons licence and your intended use is not permitted by statutory regulation or exceeds the permitted use, you will need to obtain permission directly from the copyright holder. To view a copy of this licence, visit http://creativecommons.org/licenses/by/4.0/.

\section{References}

1. Wernicke AG, Edgar MA, Lavi E, et al. Prostate-specific membrane antigen as a potential novel vascular target for treatment of glioblastoma multiforme. Arch Pathol Lab Med. 2011;135:1486-9.

2. Marafi F, Sasikumar A, Fathallah W, Esmail A. 18F-PSMA 1007 Brain PET/CT imaging in glioma recurrence. Clin Nucl Med. 2020;45:e61-2. https://doi.org/10.1097/RLU.0000000000002668.

3. Kunikowska J, Królicki B, Królicki L. Glioblastoma multiforme: another potential application for ${ }^{68} \mathrm{Ga}$-PSMA PET/CT as a guide for targeted therapy. Eur J Nucl Med Mol Imaging. 2018;45:886-7. https://doi.org/10.1007/s00259-018-3934-2.

4. Kunikowska J, Kuliński R, Muylle K, Koziara H. Królicki L ${ }^{68} \mathrm{Ga}$ PSMA-11 PET/CT: a new imaging option for recurrent glioblastoma multiforme? Clin Nucl Med. 2020;45:11-8. https://doi.org/10.1097/ RLU.0000000000002806.

5. Giammarile F, Muylle K, Delgado Bolton R, Kunikowska J, Haberkorn U, Oyen W. Dosimetry in clinical radionuclide therapy: the devil is in the detail. Eur J Nucl Med Mol Imaging. 2017;44: 2137-9. https://doi.org/10.1007/s00259-017-3820-3 Erratum in: Eur J Nucl Med Mol Imaging. 2018;45:676. doi: 10.1007/s00259-0173921-z.

Publisher's note Springer Nature remains neutral with regard to jurisdictional claims in published maps and institutional affiliations. 